\title{
Endocrinopathy in thalassaemia major
}

\author{
NEIL McINTOSH \\ From the Departments of Paediatrics, University College Hospital and Whittington Hospital, London
}

\begin{abstract}
McIntosh, N. (1976). Archives of Disease in Childhood, 51, 195. Endocrinopathy in thalassaemia major. Pituitary, adrenal, and pancreatic functions were investigated in 9 patients with thalassaemia major. 9 a.m. plasma ACTH values were $148-480 \mathrm{pg} / \mathrm{ml}$ (normal range $15-70 \mathrm{pg} / \mathrm{ml}$ ). Cortisol and growth hormone response to insulin-induced hypoglycaemia was normal in all. 24-hour urinary excretions of 17-ketosteroids and 17-hydroxycorticosteroids were normal. There was normal cortisol response to intramuscular injection of ACTH. In a physiological adrenal stimulation test there was a significantly smaller response to each physiological dose of tetracosactrin. 4 patients had diabetic glucose tolerance testsnone are clinically diabetic. The mean plasma glucose utilization constant $(\mathrm{Kgl}=$ $2 \cdot 02$ ) is significantly smaller than normal. Plasma insulin response both in the oral and the intravenous glucose tolerance test was significantly smaller than normal.

The data were consistent with severe and widespread impairment of endocrine function and a plausible explanation would be iron deposition in endocrine organs. It is suggested that pituitary hyperfunction of ACTH secretion is due to target organ unresponsiveness which can be shown in its early stages only by a physiological test of the adrenal cortex. Skin pigmentation in thalassaemia seems to be due to the melanophore-stimulating effect of this raised plasma ACTH.
\end{abstract}

Soon after the first report of thalassaemia major (Cooley and Lee, 1925), it was realized that in many cases cause of death was related to iron load, and this was identical clinically and pathologically with that seen in idiopathic haemochromatosis (Erlandson, Brilliant, and Smith, 1964; Fink, 1964). In both conditions pathological studies have shown haemosiderin deposition in liver, spleen, heart, kidney, in most endocrine organs, but not in the skin (Ellis, Schulman, and Smith, 1954). Transfusion haemosiderosis shows the same distribution, but heavier deposition, in the reticuloendothelial system, almost certainly due to the different site of haem release (Fink, 1964). The increased iron load in thalassaemia is due to blood transfusions, one unit of blood containing approximately $200 \mathrm{mg}$ of iron. It has been noted, however, that there is often a discrepancy between transfused iron load and the degree of haemosiderosis in thalassaemia. Erlandson et al. (1962) showed that patients with a number of haemolytic anaemias had increased gastrointestinal iron absorption, and this together with the iron therapy given to some patients for 'anaemia', seemed to account

Received 25 June 1975 in thalassaemia major for the increased iron that had not been transfused.

Stunting of growth in thalassaemia major is almost invariable after the first decade, but the cause remains unknown. It has been ascribed to the chronic hypoxia associated with severe anaemia, and certainly the height of these children can often be increased by high-transfusion regimens (Wolman, 1964). Hormonal insufficiency may be at least a contributory cause, suggested by the findings of massive haemosiderosis in endocrine glands at necropsy. The present investigation was undertaken to determine the extent to which the endocrine glands are affected functionally in prepubertal thalassaemia major.

\section{Methods and patients}

The age sex, and transfused iron load of the 9 patients with thalassaemia major diagnosed by blood film and haemoglobin electrophoresis are shown in Table I. The transfused iron load was calculated on the basis of $200 \mathrm{mg}$ of iron in each unit of citrated blood used (one unit contains $120 \mathrm{ml}$ sodium citrate and 420 $\mathrm{ml}$ of blood). Cases 2 and 8 have only recently come under our care and have had no prior chelation therapy. For at least 5 years all our other cases have received 
TABLE I

Age, sex, and details of iron load in 9 patients with thalassaemia major

\begin{tabular}{|c|c|c|c|c|c|c|}
\hline $\begin{array}{l}\text { Case } \\
\text { no. }\end{array}$ & $\begin{array}{c}\text { Age } \\
\text { (years) }\end{array}$ & Sex & $\begin{array}{l}\text { I.V. iron load } \\
\text { (200 mg/unit) }\end{array}$ & $\begin{array}{c}\text { Iron excreted } \\
\text { with } \\
\text { blood } \\
\text { (mg) }\end{array}$ & $\begin{array}{c}\text { Iron excreted } \\
\text { with daily } \\
\text { desferrioxamine } \\
\text { (g) }\end{array}$ & $\begin{array}{l}\text { Approx balance } \\
\text { of iron ( }(\mathrm{g})\end{array}$ \\
\hline $\begin{array}{l}1 \\
2 \\
3 \\
4 \\
5 \\
6 \\
7 \\
8 \\
9\end{array}$ & $\begin{array}{r}14 \\
12 \\
12 \\
11 \\
10 \\
10 \\
9 \\
6 \\
5\end{array}$ & $\begin{array}{l}\text { M } \\
\text { M } \\
\text { F } \\
\text { F } \\
\text { F } \\
\text { M } \\
\text { F } \\
\text { M } \\
\text { M }\end{array}$ & $\begin{array}{c}30 \mathrm{~g} \\
\text { approx } 33 \mathrm{~g} \\
1 \cdot 2 \mathrm{~g} \\
20 \mathrm{~g} \\
20 \mathrm{~g} \\
23 \mathrm{~g} \\
22 \mathrm{~g} \\
12 \mathrm{~g} \\
6 \mathrm{~g}\end{array}$ & $\begin{array}{l}3 \cdot 8 \mathrm{~g} \\
0 \\
0 \\
325 \\
430 \\
800 \\
450 \\
0 \\
96\end{array}$ & $\begin{array}{l}7 \cdot 7 \\
0 \\
0 \\
3 \cdot 6 \\
6 \\
5 \\
9 \\
0 \\
0\end{array}$ & $\begin{array}{l}+19 \\
+33 \\
+1 \cdot 2 \\
+16 \\
+13 \cdot 5 \\
+17 \\
+12 \cdot 5 \\
+12 \\
+5\end{array}$ \\
\hline
\end{tabular}

chelation intravenously with each blood transfusion, and the 5 older children have also had daily intramuscular injections of desferrioxamine $B$.

Urinary iron excretion was measured by the method of Fielding and Brunström (1964). During transfusion urine was collected from the start until 6 hours after the finish of the transfusion, and $2 \mathrm{~g}$ desferrioxamine $\mathrm{B}$ was given with each unit of blood. In patients receiving $500 \mathrm{mg}$ desferrioxamine $\mathrm{B}$ intramuscularly daily, 24hour urinary iron excretions were measured in the intertransfusion period.

An intravenous insulin test was performed using $0.1 \mathrm{unit} / \mathrm{kg}$ of soluble insulin (Roth et al., 1963). All patients had biochemical evidence of hypoglycaemia, in most cases accompanied by clinical symptoms. Growth hormone responses were measured by radioimmunoassay (Hartog et al., 1963), and cortisol responses by the fluorimetric method of Mattingly (1962). Plasma ACTH levels were measured by the radioimmunoassay technique described by Berson and Yalow (1968) using a modification by Mukherjee and Swyer (1972), the antibody being specific against $N$ terminal 1-24 ACTH and synthetic human 1-39 ACTH.

24-Hour urinary excretions of 17-ketosteroids (17 KS) and 17-hydrocorticosteroids (17 OHCS) were estimated by the MRC recommended method (Gray et al., 1969). An intramuscular ACTH stimulation test was performed (Friedman, 1967). After blood was taken at 9 a.m. for cortisol estimation, 40 units of Acthar gel (Armour Pharmaceutical Company Ltd, England) was given intramuscularly, and a second cortisol level was measured at 5 hours. A graded dose tetracosactrin stimulation test was performed on subjects whose pituitary corticotrophin secretion had been previously suppressed by $2 \mathrm{mg}$ dexamethasone 6-hourly for five doses. The cortisol response was measured to $31 \cdot 25 \mathrm{ng}, 62.5 \mathrm{ng}$, $125 \mathrm{ng}, 250 \mathrm{ng}$, and $250000 \mathrm{ng}$ intravenous tetracosactrin as described by Landon et al. (1967).

An oral glucose tolerance test was performed on fasting patients given a $50 \mathrm{~g}$ glucose load. Glucose and insulin levels were measured in venous blood at 0,15 , $30,60,90$, and 120 minutes. Intravenous glucose tolerance tests were performed on rested, fasted patients with a glucose load of $500 \mathrm{mg} / \mathrm{kg}$, body weight given over 2 minutes as described by Lundbaek (1962). From the decline in glucose concentration in the blood a glucose utilization constant, $\mathrm{Kgl}$, was obtained (Lundbaek, 1962; Loeb, 1966). The response in insulin levels was also measured. All glucose estimations were performed by an automated glucose oxidase method (Gutteridge and Wright, 1968). Insulin was measured by a double antibody radioimmunoassay (Hales and Randle, 1963).

\section{Results}

Pituitary. The results of the intravenous insulin stress test showed normal response of both growth hormone and cortisol, suggesting functional integrity of the hypothalamo-pituitary-adrenal axis. Table II shows those values, and also the 9 a.m. plasma ACTH levels which are three or four times above the normal values of Besser et al. (1971) and of Mukherjee and Swyer (1972) using the same antibody.

Adrenal. Table III and Fig. 1 show that the results of 24-hour production of $17 \mathrm{KS}$ metabolites are normal and those of the 17 OHCS metabolites are high normal for age. The ACTH stimulation tests (Table III) showed a normal or high resting cortisol level with a good response to stimulation in all but Cases 2 and 3. In Case 2 the test was repeated with a similar normal resting level and no response to stimulation. Results of the graded dose tetracosactrin stimulation test are also shown in Table III. In Fig. 2 the rise in cortisol above the fasting level is plotted against the dose of tetracosactrin given in subjects whose pituitary glands have been previously suppressed with dexamethasone. At each dose except the maximum there is a smaller response $(P<0.002)$ in the thalassaemic patients than in the normal group of Landon et al. (1967). 
Endocrinopathy in thalassaemia major

TABLE II

Pituitary function tests in thalassaemia

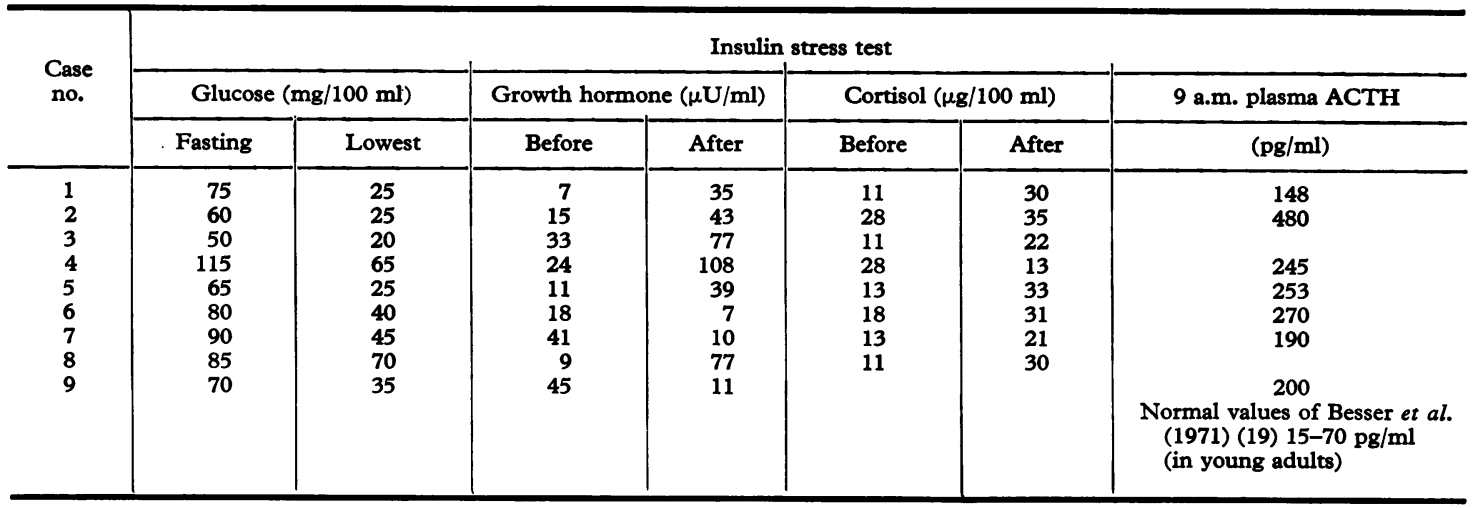

TABLE III

Adrenal function tests in thalassaemia

\begin{tabular}{|c|c|c|c|c|c|c|c|c|c|c|c|c|}
\hline \multirow[t]{2}{*}{$\begin{array}{c}\text { Case } \\
\text { no. }\end{array}$} & \multicolumn{2}{|c|}{$\begin{array}{l}\text { 24-hour urinary } \\
\text { excretion/mg }\end{array}$} & \multicolumn{2}{|c|}{$\begin{array}{l}\text { ACTH stimulation } \\
\text { test } \\
\text { (cortisol } \mu \mathrm{g} / 100 \mathrm{ml} \text { ) }\end{array}$} & \multicolumn{2}{|c|}{$\begin{array}{l}\text { Insulin toler- } \\
\text { ance test } \\
\text { (cortisol } \\
\mu \mathrm{g} / 100 \mathrm{ml})\end{array}$} & \multicolumn{6}{|c|}{$\begin{array}{c}\text { Graded dose tetracosactrin } \\
\text { stimulation test } \\
\text { (ng/dose of tetracosactrin) }\end{array}$} \\
\hline & $17 \mathrm{KS}$ & 17 OCHS & Before & After & Before & After & Resting & $31 \cdot 25$ & $\begin{array}{l}62 \cdot 5 \\
\text { (Corti }\end{array}$ & $\begin{array}{l}125 \\
\text { sol in } \mu g\end{array}$ & $\begin{array}{c}250 \\
00 \mathrm{ml})\end{array}$ & 250000 \\
\hline $\begin{array}{l}1 \\
2 \\
3 \\
4 \\
5 \\
6 \\
7 \\
8 \\
9\end{array}$ & $\begin{array}{l}3 \cdot 6 \\
4 \cdot 1 \\
1 \cdot 8 \\
1 \cdot 9 \\
1 \cdot 4 \\
2 \cdot 4 \\
2 \cdot 5 \\
1 \cdot 0 \\
1 \cdot 8\end{array}$ & $\begin{array}{r}12 \cdot 1 \\
10 \cdot 8 \\
4 \cdot 8 \\
8 \cdot 8 \\
3 \cdot 8 \\
6 \cdot 2 \\
8 \cdot 9 \\
4 \cdot 2 \\
4 \cdot 8\end{array}$ & $\begin{array}{r}13 \\
20 \\
20 \\
30 \\
35 \\
25 \\
9 \\
11 \\
16\end{array}$ & $\begin{array}{l}38 \\
18 \\
24 \\
44 \\
69 \\
53 \\
53 \\
48 \\
76\end{array}$ & $\begin{array}{l}11 \\
28 \\
11 \\
13 \\
13 \\
18 \\
13 \\
11\end{array}$ & $\begin{array}{l}30 \\
35 \\
22 \\
28 \\
33 \\
31 \\
21 \\
30\end{array}$ & $\begin{array}{l}2 \cdot 0 \\
2 \cdot 0 \\
3 \cdot 2 \\
3 \cdot 2 \\
2 \cdot 0 \\
8 \cdot 0 \\
7 \cdot 0 \\
2 \cdot 8\end{array}$ & $\begin{array}{l}2 \cdot 0 \\
2 \cdot 4 \\
2 \cdot 0 \\
- \\
3 \cdot 6 \\
7 \cdot 8 \\
6 \cdot 0 \\
3 \cdot 4\end{array}$ & $\begin{array}{l}2 \cdot 4 \\
2 \cdot 8 \\
3 \cdot 0 \\
8 \cdot 8 \\
2 \cdot 8 \\
5 \cdot 0 \\
5 \cdot 8 \\
5 \cdot 2\end{array}$ & $\begin{array}{r}1 \cdot 6 \\
4 \cdot 0 \\
2 \cdot 2 \\
11 \cdot 0 \\
8 \cdot 0 \\
4 \cdot 6 \\
6 \cdot 2 \\
6 \cdot 2\end{array}$ & $\begin{array}{r}7 \cdot 8 \\
4 \cdot 6 \\
10 \cdot 8 \\
14 \cdot 6 \\
16 \cdot 4 \\
17 \cdot 0 \\
13 \cdot 6 \\
8 \cdot 0\end{array}$ & $\begin{array}{l}26 \cdot 0 \\
13 \cdot 4 \\
17 \cdot 0 \\
21 \cdot 1 \\
35 \cdot 0 \\
39 \cdot 0 \\
32 \cdot 0 \\
14 \cdot 4\end{array}$ \\
\hline
\end{tabular}

17 KS, 17-ketosteroids; 17 OHCS, 17-hydroxycorticosteroid.

Pancreas. Table IV gives the results of oral and intravenous glucose tolerance tests and the glucose utilization constants (Kgl). Figs. 3-5 compare the results of this study with previously published series. P values are given for each comparison. In the results of the oral glucose tolerance tests, Cases 1, 2, 5, and 6 can be seen to have chemical diabetes (Milner, 1969). Comparing the thalassaemic children as a group with normal children of Etienne, Lasfargues, and Laplane (1961), glucose levels are significantly higher at zero minutes, 30 minutes, and 120 minutes in the thalassaemics. The series of Etienne et al. (1961) has been used as a comparison because values are specifically on venous as opposed to capillary blood samples. Fig. 4 compares the plasma insulin values with those obtained in normal children by
Milner (1969). The difference is highly significant at all times except for the 120-minute sample. Table V compares the peak insulin values of our patients with normals, juvenile diabetics, and growth-retarded children published by Karp, Laron, and Doron (1973). The secretion pattern does not differ significantly from the values of juvenile diabetics $(P>0 \cdot 1)$.

The glucose utilization constants $\mathrm{Kgl}$ (Table IV) in the intravenous glucose tolerance test are low (mean $\pm S E 2 \cdot 02 \pm 0 \cdot 22$ ) compared to the values of Loeb (1966) (mean \pm SE 2.66 $\pm 0 \cdot 19 ; P<0 \cdot 05$ ). Cases 4 and 6 are exceedingly low and equivalent to diabetic values. Fig. 5 shows the insluin results and compares these to normals of Crockford, Harbeck, and Williams (1966). Glucose levels (Table IV) are only significantly higher at $\mathbf{5}$ and 20 


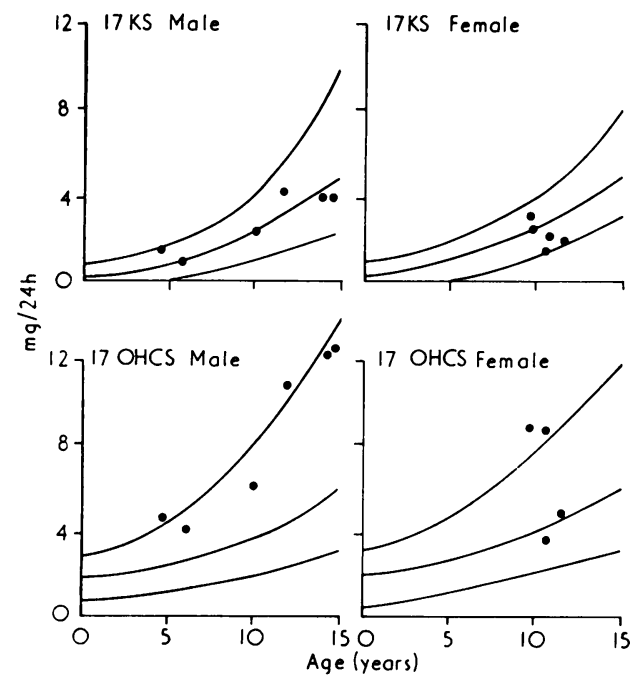

FIG. 1.-24-hour production of 17-ketosteroid (17 KS) and 17-hydroxycorticosteroid (17 OHCS) metabolites. Lines represent mean $\pm 2 S D$ of normals, from Borth, Linder, and Riondel (1957). Each - represents one thalassaemic case.

minutes, despite the exceedingly poor insulin response throughout.

\section{Discussion}

Despite the fact that iron loading in haemochromatosis is well known to produce endocrino-

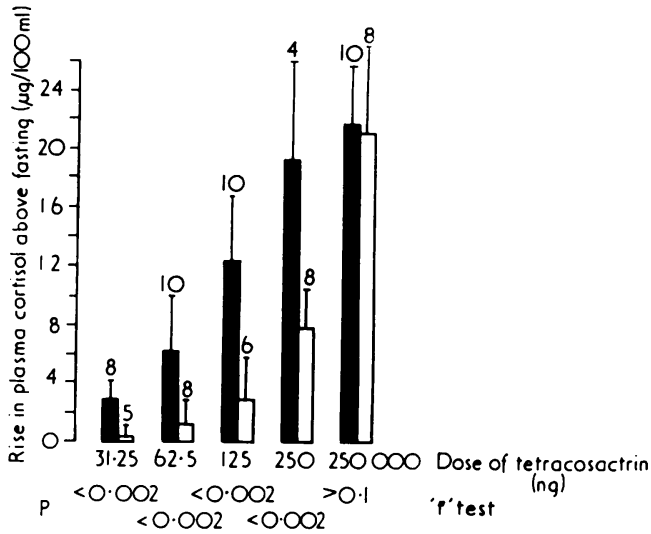

FIG. 2.-Physiological adrenal stimulation test. The increase in plasma cortisol from the fasting level is plotted in the dexamethasone-suppressed subjects given 5 increasing doses of I.V. tetracosactrin. The solid columns show mean $+2 S E$ of Landon et al. (1967) for normal adults. The open columns shown mean +2SE of our thalassaemic children. The number over each column is the number tested. Probability values are shown beneath (' $t$ ' test).

pathy, studies of endocrine function in thalassaemia, another iron loading disease, are few. Bannerman et al. (1967) were the first to report a case of thalassaemia intermedia with multiple pathology at the age of 41 years, with involvement of endocrine organs. Kuo, Zaino, and Roginsky (1968) were the first to report a series, investigating 7 patients aged from 6 to 23 years, finding low basal urinary

TABLE IV

Pancreatic function tests in thalassaemia

\begin{tabular}{|c|c|c|c|c|c|c|c|c|c|c|c|c|c|c|c|c|}
\hline \multirow{2}{*}{$\begin{array}{l}\text { Case } \\
\text { no. }\end{array}$} & & \multicolumn{6}{|c|}{ Oral glucose tolerance test (min) } & \multicolumn{8}{|c|}{ I.V. glucose tolerance test (min) } & \multirow{2}{*}{$\begin{array}{l}\text { Plasma glucose } \\
\text { utilization } \\
\text { constant } \\
(\mathrm{Kgl})\end{array}$} \\
\hline & & 0 & 15 & 30 & 60 & 90 & 120 & 0 & 5 & 10 & 20 & 30 & 40 & 50 & 60 & \\
\hline 1 & $\begin{array}{l}\text { Sugar }(\mathrm{mg} / 100 \mathrm{ml}) \\
\text { Insulin }(\mu \mathrm{U} / \mathrm{ml})\end{array}$ & $\begin{array}{r}80 \\
1\end{array}$ & $\begin{array}{r}120 \\
12\end{array}$ & $\begin{array}{r}165 \\
13\end{array}$ & $\begin{array}{r}215 \\
1\end{array}$ & $\begin{array}{r}185 \\
10\end{array}$ & $\begin{array}{r}160 \\
2\end{array}$ & - & $\begin{array}{r}275 \\
57\end{array}$ & $\begin{array}{r}240 \\
32\end{array}$ & $\begin{array}{r}205 \\
13\end{array}$ & $\begin{array}{r}175 \\
12\end{array}$ & $\begin{array}{r}160 \\
17\end{array}$ & $\begin{array}{r}150 \\
20\end{array}$ & $\begin{array}{r}130 \\
16\end{array}$ & $1 \cdot 2$ \\
\hline 2 & $\begin{array}{l}\text { Sugar } \\
\text { Insulin }\end{array}$ & 75 & 180 & 160 & 205 & 180 & 100 & $\begin{array}{r}100 \\
6\end{array}$ & $\frac{7}{17}$ & $\begin{array}{r}245 \\
23\end{array}$ & $\begin{array}{r}165 \\
9\end{array}$ & $\begin{array}{r}110 \\
5\end{array}$ & $\begin{array}{r}80 \\
5\end{array}$ & $\begin{array}{r}80 \\
2\end{array}$ & 70 & $2 \cdot 3$ \\
\hline \multirow[t]{2}{*}{3} & Sugar & 80 & 90 & 85 & 75 & 85 & 90 & 70 & 190 & 170 & 110 & 90 & 55 & 40 & 50 & $2 \cdot 1$ \\
\hline & Insulin & 4 & 16 & 18 & - & 16 & 17 & 1 & 13 & 11 & 2 & 1 & 1 & - & 1 & \\
\hline 4 & $\begin{array}{l}\text { Sugar } \\
\text { Insulin }\end{array}$ & & & & & & & 二 & 295 & $\begin{array}{r}275 \\
40\end{array}$ & $\begin{array}{r}235 \\
32\end{array}$ & $\begin{array}{r}210 \\
28\end{array}$ & $\begin{array}{r}170 \\
22\end{array}$ & $\begin{array}{r}165 \\
22\end{array}$ & $\begin{array}{r}145 \\
19\end{array}$ & $1 \cdot 25$ \\
\hline \multirow[t]{2}{*}{5} & Sugar & 90 & 120 & - & 125 & 140 & 135 & 85 & 270 & 235 & 160 & 115 & 100 & 85 & 85 & $2 \cdot 3$ \\
\hline & Insulin & 0 & 175 & 11 & 8 & 23 & 4 & 15 & 110 & 74 & 24 & 7 & 19 & 9 & 8 & \\
\hline \multirow[t]{2}{*}{6} & Sugar & 100 & 143 & 205 & 190 & 175 & 180 & 90 & 275 & 245 & 210 & 180 & 160 & 140 & 110 & $1 \cdot 26$ \\
\hline & Insulin & 7 & 5 & 17 & 28 & 26 & 31 & 4 & 18 & 16 & 8 & - & 10 & 3 & 1 & \\
\hline \multirow[t]{2}{*}{7} & Sugar & 65 & 100 & 110 & 115 & - & 95 & 95 & 260 & 230 & 150 & 110 & 90 & 95 & 105 & $2 \cdot 5$ \\
\hline & Insulin & 5 & 14 & 25 & 21 & $\overline{-}$ & 10 & 15 & 129 & 53 & 13 & 2 & 1 & 3 & 7 & \\
\hline \multirow[t]{2}{*}{8} & Sugar & 100 & 135 & 130 & 95 & 115 & 90 & 75 & 275 & 215 & 180 & - & 100 & - & 85 & $2 \cdot 2$ \\
\hline & Insulin & 1 & 12 & 13 & 1 & 10 & 2 & 1 & 7 & 5 & 3 & - & 1 & 一 & 1 & \\
\hline 9 & $\begin{array}{l}\text { Sugar } \\
\text { Insulin }\end{array}$ & $\begin{array}{r}80 \\
5\end{array}$ & $\begin{array}{r}130 \\
19\end{array}$ & $\begin{array}{r}140 \\
26\end{array}$ & $\begin{array}{r}110 \\
8\end{array}$ & 二 & $\begin{array}{l}95 \\
14\end{array}$ & $\begin{array}{l}90 \\
25\end{array}$ & $\begin{array}{l}235 \\
200\end{array}$ & 196 & 130 & $\begin{array}{l}75 \\
21\end{array}$ & $\begin{array}{l}60 \\
11\end{array}$ & 60 & 70 & $3 \cdot 1$ \\
\hline & & & & & & & & & & & & & & & & Mean $=2.02$ \\
\hline
\end{tabular}




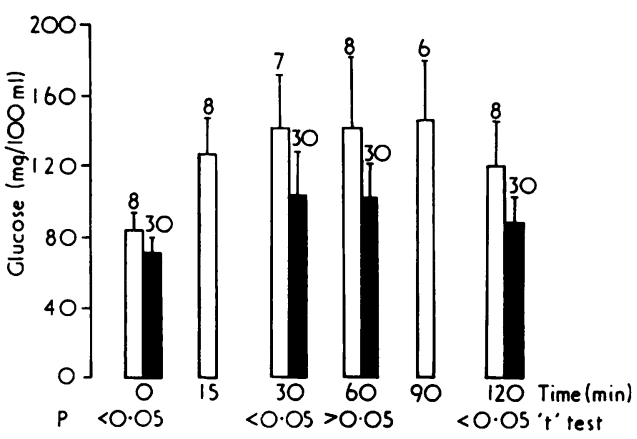

Fig. 3.-Glucose values $(\mathrm{mg} / 100 \mathrm{ml})$ on venous blood fasting and at periods after a $50 \mathrm{~g}$ glucose load. Mean $+2 S E$ of normals are shown in solid column (Etienne et al., 1961) and mean +2SE for thalassaemic patients shown in open columns. The number over each column is the number of patients tested. Probability values (' $t$ ' test) are shown beneath.

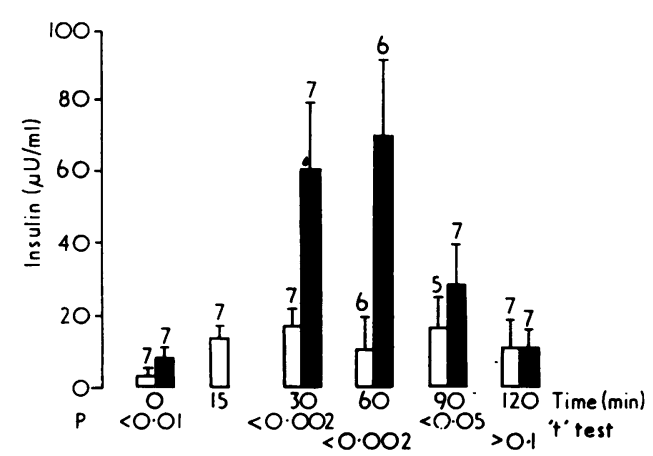

Fig. 4.-Insulin values $(\mu U / m l)$ fasting and at periods after a $50 \mathrm{~g}$ oral glucose load. Mean +2SE of normals aged 5-15 years (Milner, 1969) are shown in solid columns. Mean +2SE for thalassaemic patients are shown in open columns. The number over each column is the number of patients tested. Probability values (' $t$ ' test) are shown beneath.

17-ketosteroid levels and a poor response to metyrapone, but a normal insulin stress test. Canale et al. (1974) investigated endocrine function in 20 patients with thalassaemia major. 10 were prepubertal, and in these no abnormality of thyroid, pituitary, or adrenal function was noted. Of 10 cases aged 13 to 27 years, 9 had low urinary 17ketosteroid production, though in fact commensurate for height and bone ages. Urine and plasma hydroxycorticoid levels were normal, as was urine aldosterone. Growth hormone response to insulin was normal in all.

They concluded that only 3 transfused patients

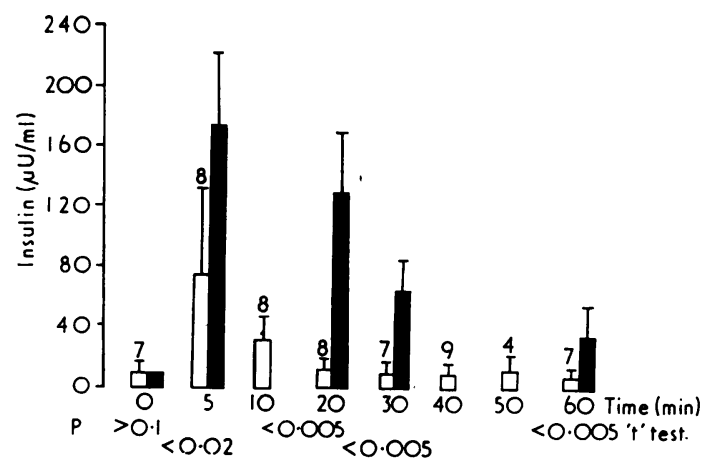

FIG. 5.-Plasma insulin values before and at intervals after $500 \mathrm{mg} / \mathrm{kg}$ intravenous glucose. Solid columns show mean +2SE of thalassaemia patients and open columns mean +2SE of young adults of Crockford et al. (1966). Number over open columns indicates the number of patients studied. Probability values (' $t$ ' test) are shown beneath.

TABLE V

Oral glucose tolerance test

\begin{tabular}{l|c|l|l|l}
\hline \multicolumn{1}{c|}{ Peak insulin values $(\mu \mathrm{U} / \mathrm{ml})$} & Mean & SD & SE & No. \\
\cline { 1 - 2 } Thalassaemic patients & 21 & $6 \cdot 8$ & $2 \cdot 6$ & 7 \\
Normals & 131 & 42 & 6 & 48 \\
Juvenile diabetics $\}$ Karp el. & 25 & 10 & 2 & 15 \\
'Growth-retarded' & 50 & 38 & 6 & 36 \\
\hline
\end{tabular}

Note: Thalassaemic values significantly lower than 'normals' and 'growth-retarded' $(P<0.002)$, and not different from diabetics $(\mathrm{P}>\mathbf{0} \cdot \mathbf{1})$.

showed loss of endocrine function after 20-24 years of transfusion, and suggested that the dysfunction could be due to end organ fibrosis. Lassman et al. (1974) investigated 8 transfusiondependent thalassaemics aged 5-31 years, 2 of whom were known to have insulin-dependent diabetes mellitus. 4 others in the series were shown to have impaired glucose tolerance. 2 postpubertal patients had abnormal metyrapone tests, and gonadal failure was thought to be secondary to pituitary hypofunction. The present study investigated only prepubertal thalassaemics, a group in which it has been suggested in published reports that endocrine abnormality is absent.

Our finding of raised resting 9 a.m. ACTH levels is important as it substantiates the results of adrenal function tests. Slate grey pigmentation was recognized to be very common in thalassaemia major soon after the original description of the disease, and indeed pigmentation is recorded in all the cases described by Lassman et al. (1974). It usually appears in the first decade of life and be- 
comes progressively more intense. Despite lack of stainable iron on histology (Ellis et al., 1954) this pigmentation has usually been assumed to be due to iron deposition. From the present study it seems likely that the pigmentation is similar to that in Addison's disease and results from increased circulating ACTH, the first 13 amino acids of which are identical with melanophore-stimulating hormone (Lee, Lerner, and Buettner-Janusch, 1961). The patient in this study who subjectively was most deeply pigmented did in fact have the highest level of resting 9 a.m. plasma ACTH.

The usual tests of adrenal function showed little impairment of function. In Cases 2 and 8 there was no response to intramuscular ACTH and this could have been because the adrenal gland was always working at maximum rate to produce the normal circulating cortisol levels. Using the more physiological graded dose adrenal cortical stimulation test (Landon et al., 1967) highly significant suppression of function was shown in the physiological range with a normal reserve of function. This could explain why there was an increase in the circulating levels of plasma ACTH, the increased levels being required to produce normal adrenocortical response. Ethical reasons prevent normal values being available for children in this test, but since completion of this study normal adult values have been obtained in younger children with thalassaemia major (McIntosh, 1976).

Highly significant impairment of pancreatic function was shown. Not only were 4 of the oral glucose tolerance tests shown to be diabetic in type, but also the peripheral glucose utilization seen in the intravenous glucose tolerance was poor. High $\mathrm{Kgl}$ values have been shown prepubertally by Loeb (1966) but in our patients, who were all prepubertal, the values were generally low, and in Cases 1,4 , and 6 they were in the diabetic range. The poor glucose tolerance was shown clearly to be related to highly significant impairment of insulin secretion, very low levels being found after oral or intravenous stimulation. Similar ethical considerations make insulin values in response to oral and intravenous glucose loads unavailable in the paediatric age group. The normal adult values quoted are probably satisfactory, indeed the youngest patient in the series had an exceedingly high response, but the data must be interpreted with some caution.

Thus in our patients $\beta$ cell pancreatic function and adrenal cortical function are both shown to be depressed, though the latter was shown only using a very sensitive test. The depression of function was seen in a virtually untransfused patient as well as in those severely iron loaded. If one postulates iron deposition as the aetiology (as seems likely with the parallel of haemochromatosis) it may be that gastrointestinally absorbed iron is more damaging than intravenously loaded iron. Even the 6-year-old patient had a poor insulin response to oral glucose load, so damage occurs early in life, and we should become even more intensive in our use of chelation therapy.

I thank Dr. Max Friedman for suggesting this study and for encouragement, and thank Dr. J. Luder; Miss B. Crowley and the staff of the Endocrine and Biochemistry Laboratories at the Whittington Hospital for various estimations; and Dr. Bernadette Modell of University College Hospital for the iron measurements.

\section{REFERENCES}

Bannerman, R. M. : Keusch, G., Kreimer-Birnbaum, M., Vance, V. K., and Vaughan, S. (1967). Thalassemia intermedia with iron overload, cardiac failure, diabetes mellitus, hypopituitarism and porphyrinuria. American fournal of Medicine, 42, 476.

Berson, S. A., and Yalow, R. S. (1968). Radioimmunoassay of A.C.T.H. in plasma. Fournal of Clinical Investigation, 47, 2725.

Besser, G. M., Cullen, D. R., Irvine, W. J., Ratcliffe, J. G., and Landon, J. (1971). Immunoreactive corticotrophin levels in adrenocortical insufficiency. British Medical fournal, 1, 374.

Borth, R., Linder, A., and Riondel, A. (1957). Urinary excretion of 17-hydroxycorticosteroids and 17 ketosteroids in healthy subjects, in relation to sex, age, bodyweight and height. Acta Endocrinologia, 25, 33.

Canale, V. C., Steinherz, P., New, M., and Erlandson, M. (1974). Endocrine function in thalassemia major. Annals of New York Academy of Sciences, 232, 333.

Cooley, T. B., and Lee, P. (1925). A series of cases of splenomegaly in children with anemia and peculiar bone changes. American Fournal of Diseases of Children, 30, 447.

Crockford, P. M., Harbeck, R. J., and Williams, R. H. (1966). Influence of age on intravenous glucose tolerance and severe immunoreactive insulin. Lancet, 1, 465.

Ellis, J. T., Schulman, I., and Smith, C. H. (1954). Generalized siderosis with fibrosis of liver and pancreas in Cooley's (Mediterranean) anemia. American fournal of Pathology, 30, 287.

Erlandson, M. E., Brilliant, R., and Smith, C. H. (1964). Comparison of 66 patients with thalassemia major and 13 patients with thalassemia intermedir, including evaluations of growth, development, maturation and prognosis. Annals of New York Academy of Sciences, 119, 727

Erlandson. M. E.. Walden, B., Stern, G., Hilgartner, M. W., Wehman, J., and Smith, C. H. (1962). Studies on congenital hemolytic syndromes. IV. Gastro-intestinal absorption of iron. Blood, 19, 359.

Etienne, M., Lasfargues, G., and Laplane, R., (1961). L'étape musculaire du métabolisme du glucose chez l'enfant obése. Presse Médicale, 69, 1587.

Fielding; J., and Brunström, G. M. (1964). Estimation of ferrioxamine and desferrioxamine in urine. Fournal of Clinical Patho$\log y, 17,395$.

Fink, H. E. (1964). Transfusion hemochromatosis in Cooley's anemia. Annals of New York Academy of Sciences, 119, 680.

Friedman, M. (1967). Comparison of duration of activity of corticotrophin-gelatin and corticotrophin-carboxymethyl cellulose. British Medical fournal, 3, 409.

Gray, C. H., Baron, D. N., Brooks, R. V., and James, V. H. T. (1969). A critical appraisal of a method of estimating urinary 17-oxosteroids and total 17 oxogenic steroids. Lancet, 1, 124.

Gutteridge, J., and Wright, E. B. (1968). A simple automated glucose oxidase method. Fournal of Medical Laboratory Techno$\log y, 25,385$.

Hales, C. N., and Randle, P. J. (1963). Immunoassay of insulin with insulin antibody precipitate. Biochemical fournal, 88, 137. 
Hartog, M., Gaafar, M. A., Meisser, B., and Russell, Fraser (1963). Immunoassay of serum growth hormone in acromegalic patients. British Medical fournal, 2, 1229.

Karp, M., Laron, Z., and Doron, M. (1973). Insulin secretion in children with constitutional familial short stature. Fournal of Paediatrics, 83, 241.

Kuo, B., Zaino, E.. and Roginsky, M. S. (1968). Endocrine function in thalassemia major. Fournal of Clinical Endocrinology, 28, 805.

Landon, J., James, V. H. T., Wharton, M. J., and Friedman, M. (1967). Threshold adrenocortical sensitivity in man and its possible application to corticotrophin bioassay. Lancet, $\mathbf{2}$, 697.

Lassman, M. N., O'Brien, R. T., Pearson, H. A., Wise, J. K., Donabedian, R. K., Felig, P., and Genel, M. (1974). Endrocrine evaluation of thalassemia major. Annals of New York Academy of Sciences, 232, 226.

Lee, T. H., Lerner, A. B., and Buettner-Janusch, V. (1961). The isolation and structure of $\alpha$ and $\beta$ melanocyte-stimulating hormones from monkey pituitary glands. Fournal of Biological Chemistry, 236, 1390.

Loeb, H. (1966). Variations in glucose tolerance in infancy and childhood, Fournal of Pediatrics, 68, 237.

Lundbaek, K. (1962). Intravenous glucose tolerance as a tool in definition and diagnosis of diabetes mellitus. British Medical fournal, 1, 1507.
McIntosh, N. (1976). Threshold adrenocortical function in children with thalassaemia. Fournal of Endocrinology. 68. 159.

Mattingly, D. (1962). A simple fluorimetric method for the estimation of free 11-hydroxycorticoids in human plasma. fournal of Clinical Pathology, 15, 374.

Milner, A. D. (1969). Blood glucose and serum insulin levels in children with cystic fibrosis. Archives of Disease in Childhood, 44, 351 .

Mukheriee, K., and Swyer, G. I. M. (1972). Plasma cortisol and adreno-corticotrophic hormone in normal man and non-pregnant woman, normal pregnant women and women with preeclampsia. Fournal of Obstetrics and Gynaecology of the British Commonwealth, 79, 504.

Roth, J., Glick, S. M., Yalow, R. S., and Berson, S. A. (1963). Hypoglycemia-a potent stimulus to secretion of growth hormone. Science, 140, 987.

Wolman, I. J. (1964). Transfusion therapy in Cooley's anemiagrowth and health as related to long-range hemoglobin levelsa progress report. Annals of New York Academy of Sciences, $119,736$.

Correspondence to Dr. N. McIntosh, 4615 Irving Street, Apt. 4, San Francisco, California 94122, U.S.A. 